\title{
Bone marker reference range study: a comparison of the manufacturer's reference range and laboratory healthy volunteer results to patients with rheumatoid arthritis
}

\author{
Gillian Wheater ${ }^{1 *}$, Mohsen Elshahaly², Stephen P Tuck ${ }^{2,3}$, John Drury', Jaap M van Laar ${ }^{2,3}$
}

From Northern and Yorkshire Deaneries Annual Rheumatology Conference

York, UK. 26 September 2012

\section{Background}

Biochemical markers of bone turnover have been used in research for a long time and are now being recognised as helpful tools in the clinical management of bone disease. It is important to establish robust reference values for the interpretation of these markers. In addition to standardising pre-analytical variability it is unclear whether manufacturer's ranges take into account global differences between subjects and so each laboratory should investigate the transferability of the expected values to its own patient population and if necessary determine its own reference ranges.

\section{Materials and methods}

Serum samples from 70 healthy volunteers were analysed for biochemical markers of bone formation (pro- collagen type I amino-terminal propeptide [P1NP] and osteocalcin $[\mathrm{OC}]$ ) and bone resorption (beta carboxyterminal cross-linking telopeptide of bone collagen $[\beta C T X]$ on the Roche Elecsys 2010 . The results were compared to the manufacturer's reference range and to 46 samples from patients with severe refractory rheumatoid arthritis prior to treatment with rituximab.

\section{Results}

We found substantial inter-person variability in all of the biomarkers and differences between the manufacturer and healthy control ranges (Table 1).

\section{Conclusions}

These results demonstrate the large between-person variability in serum bone markers and the differences

Table 1 Comparison of bone marker results between manufacturer, healthy controls and rheumatoid arthritis patients

\begin{tabular}{|c|c|c|c|c|c|c|c|c|c|}
\hline & \multicolumn{3}{|c|}{ Manufacturer } & \multicolumn{3}{|c|}{ Healthy controls } & \multicolumn{3}{|c|}{ Rheumatoid arthritis } \\
\hline & Pre $^{c}$ & Post $^{d}$ & Male & Pre $^{c}$ & Post $^{d}$ & Male & Pre $^{c}$ & Post $^{d}$ & Male \\
\hline $\begin{array}{l}\beta C \mathrm{TX}^{\mathrm{a}} \\
\mathrm{ng} / \mathrm{L}\end{array}$ & $\begin{array}{l}299 \\
\pm 274\end{array}$ & $\begin{array}{l}556 \\
\pm 452\end{array}$ & $\begin{array}{l}300 \\
\pm 284\end{array}$ & $\begin{array}{l}192 \\
\pm 196\end{array}$ & $\begin{array}{l}199 \\
\pm 264\end{array}$ & $\begin{array}{l}325 \\
\pm 382\end{array}$ & $\begin{array}{l}139 \\
\pm 184\end{array}$ & $\begin{array}{l}354 \\
\pm 572\end{array}$ & $\begin{array}{l}337 \\
\pm 410\end{array}$ \\
\hline $\begin{array}{l}\mathrm{P} 1 \mathrm{NP} \mathrm{b}^{\mathrm{b}} \\
\mu \mathrm{g} / \mathrm{L}\end{array}$ & $\begin{array}{l}27.8 \\
15-59\end{array}$ & $\begin{array}{l}37.1 \\
16-74\end{array}$ & No data & $\begin{array}{l}31.9 \\
22-58\end{array}$ & $\begin{array}{l}32.6 \\
18-66\end{array}$ & $\begin{array}{l}51.5 \\
22-79\end{array}$ & $\begin{array}{l}30.1 \\
11-50\end{array}$ & $\begin{array}{l}39.1 \\
12-73\end{array}$ & $\begin{array}{l}40.5 \\
13-81\end{array}$ \\
\hline $\begin{array}{l}O C^{b} \\
\mu g / L\end{array}$ & $\begin{array}{l}23.0 \\
11-43\end{array}$ & $\begin{array}{l}27.0 \\
15-46\end{array}$ & $\begin{array}{l}25.0 \\
14-42\end{array}$ & $\begin{array}{l}14.9 \\
11-26\end{array}$ & $\begin{array}{l}15.3 \\
10-22\end{array}$ & $\begin{array}{l}20.2 \\
14-36\end{array}$ & $\begin{array}{l}12.4 \\
5-21\end{array}$ & $\begin{array}{l}15.3 \\
6-40\end{array}$ & $\begin{array}{l}19.6 \\
4-42\end{array}$ \\
\hline
\end{tabular}

${ }^{a}$ mean \pm 2 standard deviations (as reported by manufacturer); ${ }^{b}$ median plus interquartile range (as reported by manufacturer); ${ }^{c}$ pre-menopausal female; ${ }^{\mathrm{d}}$ post-menopausal female

\footnotetext{
* Correspondence: gill.wheater@stees.nhs.uk

${ }^{1}$ Biochemistry Department, The James Cook University Hospital,

Middlesbrough, Cleveland, TS4 3BW, UK

Full list of author information is available at the end of the article
} 
between defined 'healthy control' ranges, this can be critical when assessing patients with bone disease. We suggest that it is therefore important for each laboratory to investigate the transferability of the quoted reference range to its own patient population based on equivalent standardised collection conditions, and where necessary determine its own ranges. We recognize that it is often difficult to recruit sufficient healthy volunteers but the widespread availability of automated bone marker assays now means that harmonisation of methods and specific reference ranges may be possible using well-characterised populations in larger cohorts.

\section{Acknowledgements}

The authors wish to thank staff from the Biochemistry laboratory at the James Cook University Hospital in Middlesbrough, in particular we acknowledge Cheryl Goodrum for analysing the samples.

\section{Author details}

${ }^{1}$ Biochemistry Department, The James Cook University Hospital, Middlesbrough, Cleveland, TS4 3BW, UK. '2Musculoskeletal Research Group, Institute of Cellular Medicine, Newcastle University, Newcastle-upon-Tyne, NE1 7RU, UK. ${ }^{3}$ Rheumatology Department, The James Cook University Hospital, Middlesbrough, Cleveland, TS4 3BW, UK.

Published: 14 February 2013

doi:10.1186/1471-2474-14-S1-A3

Cite this article as: Wheater et al:: Bone marker reference range study: a comparison of the manufacturer's reference range and laboratory healthy volunteer results to patients with rheumatoid arthritis. BMC Musculoskeletal Disorders 2013 14(Suppl 1):A3.

\section{Submit your next manuscript to BioMed Central} and take full advantage of:

- Convenient online submission

- Thorough peer review

- No space constraints or color figure charges

- Immediate publication on acceptance

- Inclusion in PubMed, CAS, Scopus and Google Scholar

- Research which is freely available for redistribution

Submit your manuscript at www.biomedcentral.com/submit 